\title{
PENGELOLAAN WAKAF TUNAI MUHAMMADIYAH MELALUI SISTEM INFORMASI DIGITAL TERHADAP PETANI INDONESIA
}

\author{
Zaini Muchlis \\ Universitas Muhammadiyah Yogyakarta, Indonesia \\ Email: Zaini.muchlis@umy.ac.id \\ Yayat Hidayat \\ Universitas Muhammadiyah Yogyakarta, Indonesia \\ Email: Yayat.hidayat@umy.ac.id
}

\begin{abstract}
This study aims to provide a solution to the problem of poverty that afflicts farmers in Indonesia, today this problem still does not resolve by government or any institutions that are actively handling these matters. This research used qualitative descriptive method by gathering information, applying observation and documentation. The variables studied include the waqf fund management and its distribution through digital applications that make it easier for farmers to get the business capital. Muhammadiyah is one of the organizations engaged in the social field which has a huge potential in providing alternative solutions to the problems that plague farmers, through cash waqf from waqf institution of Muhammadiyah (BWM) hopefully can provide the solution towards this matter. Waqf funds managed by Muhammadiyah are very big and spacious, if this institution can manage properly and optimized through a digital information system will be able to provide solutions to the problems of farmers in Indonesia.
\end{abstract}

Keywords: Cash Waqf, BWM, Farmer Poverty.

\begin{abstract}
Abstrak
Penelitian ini bertujuan untuk memberikan solusi terhadap permasalahan kemiskinan yang melanda para petani di Indonesia yang saat ini masih menjadi sebuah problematika yang belum dapat diselesaikan oleh pemerintah ataupun institusi yang bergerak aktif dalam mengatasi permasalahan tersebut. Corak penelitian ini menggunakan metode deskriptif kualitatif dengan pengumpulan informasi, menerapkan observasi dan dokumentasi. Adapun variable yang diteliti meliputi metode program pengelolaan dana wakaf dan pendistribusiannya melalui sebuah aplikasi digital yang memudahkan petani dalam mendapatkan sebuah modal usaha. Muhammadiyah menjadi salah satu persyarikatan yang bergerak dalam bidang sosial memiliki potensi yang sangat besar dalam memberikan solusi alternative terhadap permasalahan yang melanda para petani, yaitu dengan pengelolaan wakaf tunai melalui lembaga badan wakaf Muhammadiyah (BWM). Dana wakaf yang dikelola
\end{abstract}

Nur El-Islam, Volume 7, Nomor 2, Oktober 2020 
oleh Muhammadiyah sangatlah besar sehingga jika dikelola dengan baik dan dioptimalkan melalui system informasi digital akan dapat memberikan solusi terhadap permasalahan para petani di Indonesia.

Kata kunci: Wakaf tunai, BWM, Kemiskinan petani.

\section{A. Pendahuluan \\ 1. Latar Belakang}

Sektor pertanian di Indonesia mampu berkontribusi terhadap pertumbuhan perekonomian sebesar $\mathrm{Rp}$ 1005,4 triliun ke Produk Domestik Bruto (PDB) pada tahun 2018. Kekayaan sektor pertanian ini belum diimbangi dengan tingkat kesejahteraan di kalangan Petani, seperti yang dipaparkan Badan Pusat Statistik (BPS) bahwa pada tahun 2018 angka kemiskinan di pedesaan yang mayoritas masyarakatnya berprofesi sebagai Petani mencapai 56 persen atau sebanyak 15,81 juta jiwa dari 25,95 juta jiwa total penduduk miskin di Indonesia. ${ }^{1}$ Kepemilikan modal, keterbatasan lahan dan akses serta rendahnya pendidikan dan teknologi menjadi penyebab keterpurukannya Petani. Ketika Petani sulit mendapatkan modal dari beberapa lembaga keuangan, mereka akan lari ke tengkulak. Melalui tengkulak, Petani akan mendapatkan bantuan modal dengan persyaratan Petani harus menjual hasil panennya ke tengkulak dengan harga rendah. ${ }^{2}$ Keberadaan tengkulak bagi Petani tidak disadari dapat merugikan Petani sendiri.

Melakukan jual beli melalui tengkulak sudah dijelaskan dalam Al-Hadits, Rasulullah telah menyampaikan bahwasanya orang-orang kota janganlah menjadi perantara bagi orang-orang desa untuk menjualkan barang dagangannya. Beberapa Ulama' menyimpulkan bahwa apabila penduduk desa tersebut sudah mengetahui harga pasar dan sama sama suka maka dianggap sah dalam pelaksanaan jual beli

1 https://www.bps.go.id/pressrelease/2019/01/15/1549/persentase-pendudukmiskin-pada-september-2018-sebesar-9-66-persen.html. Diakses pada tanggal 17 Juli 2019.

${ }^{2}$ Hardinawati L, Fauzy M, Alasan Petani Muslim Menjual Hasil Panen Kepada Tengkulak di Desa Glagahagung, Kecamatan Purwoharjo, Kabupaten Banyuwangi. Proceeding 9 th ISDEV International Islamic Development Management Conference 2015. 
hasil panennya, namun jika penduduk desa tidak mengetahui harga pasar maka jual beli tersebut dianggap tidak sah. Berikut Hadits yang menjelaskannya:

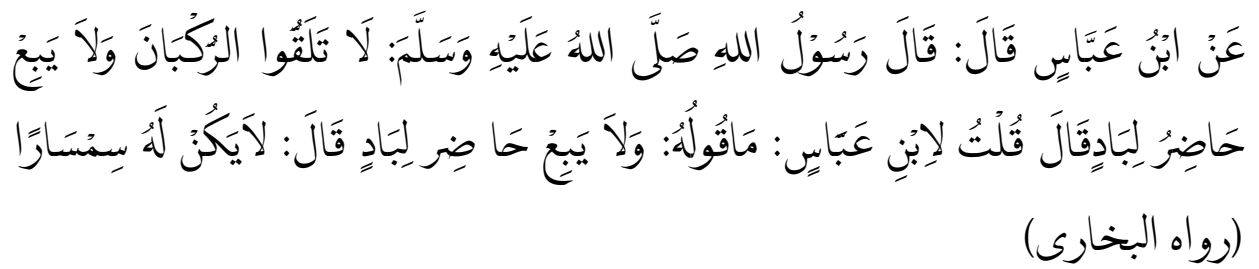

“Dari Ibnu Abbas ia berkata: telah bersabda Rasulullah saw: "Janganlah kamu mencegat kafilah-kafilah dan janganlah orang-orang kota menjual buat orang desa." saya bertanya kepada IbnuAbbas," Apa arti sabdanya?"Janganlah kamu mencegat kafilah-kafilah dan jangan orangorang kota menjualkan buat orang desa,"Ia menjawab: "Artinya janganlah ia menjadi perantara baginya (HR. Bukhori) ${ }^{3}$.

Dalam ajaran Islam, upaya-upaya pengentasan kemiskinan sudah diterangkan didalamnya dengan sangat detail, salah satunya yaitu melalui manajemen wakaf tunai. Melalui pengoptimalisasian dalam pengelolaan wakaf tunai secara baik dan benar yang dilakukan oleh lembaga wakaf yang ada di Indonesia dapat meningkatkan hasil pertanian yang berdampak pula kepada kesejahteraan para petani. Menurut Badan Amal Inggris, Charities Aid Foundation (CAF), Indonesia telah dinobatkan sebagai negara paling dermawan di dunia tahun 2018. Tingkat kedermawanan ini didukung dengan jumlah populasi masyarakat Muslim yang menjadi populasi Muslim terbesar di dunia, dengan penganut agama Islam sebesar 209,1 juta jiwa atau 87,2 persen dari seluruh total penduduk. Banyaknya jumlah masyarakat Muslim tersebut membuat Indonesia memiliki potensi besar dalam pengembangan dana filantropi Islam seperti wakaf tunai. Potensi wakaf tunai menurut data dari Badan Wakaf Indonesia (BWI) tahun 2018 mencapai sebesar Rp 180 triliun.

${ }^{3}$ Abi Abdillah Muhammad bin Ismail al-Bukhari, Shahih Bukhari (Semarang: Toha Putera, Juz 3 2009), h.201. 
Muhammadiyah sebagai salah satu persyarikatan terbesar di Indonesia telah mendapat pengakuan dalam pengelolaan wakaf sejak tahun 1972, yaitu ketika setelah ditunjuknya Muhammadiyah sebagai nazir wakaf yang memiliki badan hukum melalui surat Keputusan Dalam Negeri No. SK. 14/DDA/1972. Dengan adanya badan wakaf yang dikelola muhammadiyah ini diharapkan dapat memberikan solusi terhadap problematika yang dihadapi para petani di Indonesia. Dengan berkolaborasi dengan badan wakaf Indonesia dalam koordinasi dan pengelolaan wakaf tunai melalui system digital yang terintegrasi dengan social media, sehingga masyarakat lebih mudah dalam mendapatkan informasi mengenai wakaf.

Gagasan ini hadir dari melihat potensi dana filantropi Islam khususnya wakaf tunai di Indonesia yang sangat besar sehingga dapat dikembangkan dan diterapkan sebagai solusi alternatif pendanaan bagi Petani di seluruh nusantara. Sasaran dari gagasan ini adalah para petani di Indonesia dalam meningkatkan kesejahteraannya melalui hasil produk pertaniannya dan juga kemudahan masyarakat petani dalam mendapatkan modal usaha. Melalui pemanfaatan teknologi saat ini, penulis membentuk dan mengembangkan aplikasi Tanimu.com sebagai sarana dalam pengelolaan dana wakaf tunai yang dapat disalurkan oleh masyarakat untuk para petani di Indonesia, sehingga diharapkan masyarakat petani dapat terbantu dalam meningkatkan hasil pertaniannya. Adapun teknis pengelolaan dana wakaf melalui aplikasi tersebut akan diintegrasikan dengan Badan Wakaf Muhammadiyah (BWM) dan Badan Usaha Milik Desa (BUMDes).

Penelitian ini bertujuan menganalisis perkembangan sektor pertanian di Indonesia serta upaya peningkatan kesejahtraannya melalui program wakaf digital. Jenis penelitian ini adalah deskriptif kualitatif. Adapun variable yang diteliti meliputi metode program pengelolaan dana wakaf dan pendistribusiannya melalui sebuah aplikasi digital yang memudahkan petani dalam mendapatkan sebuah modal usaha sehingga memberikan solusi bagi permasalahan yang dihadapi para petani di Indonesia. Tahapan dalam pelaksanaan penelitian ini yaitu dengan cara mengumpukan data melalui dokumentasi, observasi terhadap para petani dan juga terhadap Badan 
Wakaf Muhammadiyah sebagai wadah pendistribusian dana wakaf untuk para petani di Indonesia.

\section{Tujuan Penulisan}

a. Mengembangkan sektor pertanian melalui inovasi dana wakaf tunai berbasis digital untuk meningkatkan kesejahteraan petani di Indonesia.

b. Menciptakan dan mengembangkan mekanisme sistem informasi digital sebagai penghimpun dan tata kelola dana wakaf tunai untuk mengembangkan sektor pertanian di Indonesia.

c. Pemberdayaan para petani menggunakan konsep sinergitas para stakeholder.

\section{Manfaat Penulisan}

1. Menjadikan solusi inovatif pengelolaan dana wakaf tunai dan memadukan peran serta stakeholder dalam menyikapi permasalahan kemiskinan yang dialami petani.

2. Memberikan gagasan pengelolaan wakat tunai dengan menggunakan sistem teknologi

3. informasi yang dapat memecahkan problematika petani di Indonesia.

4. Menjadikan petani yang mengerti akan teknologi dan berpendidikan.

B. Pembahasan

1. Landasan Teori

a. Dasar Hukum Wakaf

Islam telah mengatur segala tata cara dan juga hukum yang berkaitan dengan wakaf, sebagaimana terdapat pada Al-Quran dan Hadits berikut:

a) Q.S. Ali Imran: 92 "Kamu belum mencapai kebaikan (yang sempurna) sebelum kamu menafkahkan sebagian harta yang kamu 
cintai, dan apa saja dari sesuatu yang kamu nafkahkan, maka sesungguhnya Allah Maha Mengetahuinya".

b) Q.S. Al- Hajj: 77 "Berbuat baiklah semoga kamu bahagia (menang)". ${ }^{5}$

c) Hadits Bukhori \& Muslim, Diriwayatkan dari Abdullah bin Umar: Umar bin Khattab berkata kepada Rasulullah SAW: "Ya Rasulullah, sesungguhnya aku memiliki sebidang tanah di Khaibar, yang aku belum pernah memiliki tanah sebaik itu. Apa nasihat engkau kepadaku?" Rasulullah SAW menjawab: "Jika engkau mau, wakafkanlah tanah itu kemudian sedekahkanlah hasilnya. ${ }^{6}$

d) Hadits Bukhori, Diriwayatkan dari Amar Ibnu al-Harits, saudara Juwairiyyah Ummul Mukminin berkata: “Waktu wafat Rasulullah Saw tidak meninggalkan dirham, dinar, hamba laki-laki, hamba perempuan, dan sesuatu pun selain keledai putih, senjata, dan tanah beliau yang telah diwakafkan". ${ }^{7}$

\section{b. Definisi Wakaf dalam Fiqih}

1) Madzhab Syafi'i

Al-Minawi mendefinisikan wakaf dengan: "Menahan harta benda yang dimiliki dan menyalurkan manfaatnya dengan tetap menjaga pokok barang dan keabadiannya yang berasal dari para dermawan atau pihak umum selain dari harta maksiat semata-mata karena ingin mendekatkan diri kepada Allah SWT". ${ }^{8}$

Imam Nawawi mendefinisikan wakaf sebagai: "Penahanan harta yang bisa dimanfaatkan dengan tetap menjaga keutuhan barangnya, terlepas dari campur tangan wakif atau lainnya, dan hasilnya disalurkan

${ }^{4}$ Departemen Agama RI. Al-Qur'an dan Terjemahan (Semarang: CV Toha Putra, 2010), h. 91.

${ }^{5}$ Ibid, h. 523.

${ }^{6}$ Abi Abdillah Muhammad bin Ismail al-Bukhari. Shahih Bukhari (Semarang Toha Putera, Juz 3, t.th), h. 185.

${ }^{7}$ Ibid, h. 187.

${ }^{8}$ Al-Minawi, Muhammad bin abdul Ra'uf. At-Taufiq ala Muhimat Ta'rif (Mesir: Alamul Qutub, 1990), h. 340. 
untuk kebaikan semata-mata untuk taqarrub (mendekatkan diri) pada Allah SWT". ${ }^{9}$

2) Madzhab Hanafi

Al-Kabisi dalam kitab Anis Al-Fuqaha' mendefinisikan wakaf dengan: "Menahan benda dalam kepemilikan wakif dan menyedekahkan manfaatnya kepada orang-orang miskin dengan tetap menjaga keutuhan bendanya". ${ }^{10}$ Al-Kabisi mengemukakan definisi alternatif dan mengatakan bahwa wakaf adalah: "Menahan harta yang secara hukum menjadi milik Allah SWT."

3) Madzhab Maliki

Al-Khattab dalam kitab Mawahib Al-Jalil menyebutkan definisi Ibnu Arafah Al-Maliki dan mengatakan wakaf adalah: "Memberikan manfaat sesuatu ketika sesuatu itu ada dan bersifat lazim (harus) dalam kepemilikan pemberinya sekalipun hanya bersifat simbolis". ${ }^{11}$ Dalam kamus ekonomi, Nazih Hamam mendefinisikan wakaf dengan menahan pokok harta dan menyalurkan hasilnya.

\section{c) Perspektif Wakaf Tunai Menurut Para Ulama}

Sejarah mencatat bahwa wakaf tunai (cash wakaf) telah dijalankan sejak awal abad kedua hijriah. Imam Bukhari meriwayatkan bahwa Imam Az-Zuhri (124 H) salah seorang ulama terkemuka dan peletak dasar tadwin al hadits telah menetapkan fatwa. Masyarakat Muslim dianjurkan menunaikan wakaf menggunakan dinar dan dirham untuk pembangunan sarana dakwah, sosial, serta pendidikan umat Islam. Caranya, menjadikan uang itu sebagai modal usaha kemudian menyalurkan keuntungannya untuk wakaf. Selain itu, Imam Malik dalam buku Al-Mudawwanah, secara terang-terangan juga telah memperbolehkan adanya wakaf tunai, termasuk emas dan perak dan

9 An-Nawawi, Abu Zakaria Muhyiddin bin Syaraf, Tahrir Al-Fazh at-Tanbih (Damaskus: Darul Qolam, 1987), h. 106.

${ }^{10}$ Al-Kabisi, Muhammad abid Abdullah, Anis Al-Fuqaha' (Jeddah: Al-Wafa' li AnNashr wa Tauzi', 1987), h. 41.

${ }^{11}$ Al-Khattab, Abu Abdullah Muhammad bin Muhammad bin Abdurrahman alMaghribi, Mawahibul Jalil ala Mukhtashar Khalil (Beirut: Dar al-Kutub Ilmiah, 1992), h. 61. 
apabila wakaf tersebut rusak dan nilainya hilang maka wakaf itu dibagikan kepada orang-orang yang berhak atas wakaf itu (AlMudawwanah, bab Pinjaman, Pinjaman Dinar dan Dirham).

Meskipun tergolong baru, di Indonesia juga telah memperbolehkan penggunaan dana wakaf tunai. Sesuai dengan fatwa Majelis Ulama Indonesia (MUI) tertanggal 26 April 2002 bahwa wakaf tunai adalah wakaf uang (Cash Wakaf/wakaf al-nuqud) yaitu wakaf yang dilakukan oleh seseorang, kelompok orang, lembaga atau badan hukum dalam bentuk uang tunai.

\section{Pembahasan Penelitian}

a) Kondisi Terkini

Kemiskinan menjadi masalah yang masih terus melekat pada Petani di Indonesia. Menurut data BPS (2017), penduduk miskin di Indonesia mencapai 26,58 juta jiwa, diantaranya adalah masyarakat pedesaan yang umumnya bekerja sebagai Petani. Data BPS tahun 2019 juga menunjukkan Nilai Tukar Petani (NTP) nasional April 2019 sebesar 102,23 atau turun 0,49 persen dibanding NTP bulan sebelumnya. Penurunan NTP dikarenakan Indeks Harga yang Diterima Petani (It) naik sebesar 0,12 persen, lebih rendah dibandingkan dengan kenaikan Indeks Harga yang Dibayar Petani (Ib) sebesar 0,61 persen. NTP merupakan salah satu indikator untuk melihat tingkat kemampuan/daya beli Petani, oleh karenanya berdasarkan data, Petani saat ini mengalami kerugian dan menunjukkan tingkat kemampuan/daya beli semakin rendah. Kendala yang dihadapi Petani saat ini yaitu masih kesulitan mendapatkan pinjaman dari bank, ditambah dengan adanya persyaratan bunga. Selain itu, permasalahan bagi petani yang lain yaitu kesulitan untuk mengakses input pertanian yang berkualitas dan juga teknologi yang baru. ${ }^{12}$

Sementara itu, era revolusi industri 4.0 seperti saat ini ditandai dengan perkembangan teknologi yang pesat dan semua kegiatan yang

${ }^{12}$ Hadad, Muliaman, Stabilitas vs Pertumbuhan: Peranan Sektor Jasa Keuangan Dalam Perekonomian dan Tantangannya di Masa Depan 2018, Orasi Ilmiah Guru Besar di Undip Semarang 2018. 
bergantung dengan internet. Bahkan internet dan akses terhadap media sosial menempatkan diri sebagai kebutuhan pokok harus dipenuhi oleh setaiap generasi millenial. Berdasarakan data dari Kominfo pada tahun 2017, jumlah pengguna internet telah mencapai 143,26 juta jiwa atau 54,68 persen dari total jumlah penduduk Indonesia. Jumlah tersebut menunjukan kenaikan sebesar 10,56 juta jiwa dari hasil survei pada tahun $2016 .{ }^{13}$ Sedangkan angka penetrasi pengguna internet kedua terbesar berdasarkan tingkat ekonomi, yakni berturut-turut berada pada masyarakat menengah bagian bawah sebesar 74,62 persen, dan masyarakat mengengah bagian atas sebesar 16,02 persen. Hal tersebut menunjukan saat ini, manfaat dari internet tidak hanya dapat diakses oleh kalangan atas saja.

Oleh karena itu, hal yang perlu di kaji dalam permasalahan ini adalah terkait dengan permodalan yang dibutuhkan oleh para Petani untuk dapat bertani dengan baik dan meningkatkan hasil panennya. Seperti untuk memenuhi pembelian bibit, pupuk dan alat-alat pertanian agar Petani lebih efisien dalam bercocok tanam. Selain itu, masalah pemasaran yang efektif dan modern juga perlu dikaji karena pada umumnya petani desa hanya memasarkan hasil panennya dengan cara yang sederhana dan kurang efektif untuk mendapatkan hasil penjualan yang maksimal.

\section{b) Solusi Terdahulu}

Pemerintah telah memberikan beberapa solusi, salah satunya yaitu berupa KUR (Kredit Usaha Rakyat) untuk mengatasi adanya kemiskinan petani desa yang disebabkan karena sulitnya mencari permodalan/pembiayaan. KUR sendiri memiliki keunggulan tidak mengharuskan adanya agunan dari nasabah, namun dalam praktiknya bank tidak akan memberikan kredit kepada petani tanpa adanya agunan. Selain KUR, Pemerintah mempunyai program pemberdayaan kepada masyarakat desa, sebagai bentuk implementasi dari otonomi terus-lakukan-percepatan-pembangunan-broadband/0 /siaran_pers. Diakses pada Tanggal 25 Mei 2019. 
desa yang merupakan hasil turunan dari otonomi daerah yaitu Badan Usaha Milik Desa (BUMDes). Melihat potensinya sendiri, menurut Sekretaris Jendral Kemendes PDTT dalam Detiknews.com tahun 2017 terjadi peningkatan dalam jumlah BUMDes dari 18 ribu sekarang menjadi 22 ribu. Namun sayangnya, dari jumlah 22 ribu BUMDes tersebut belum optimal hanya 50 BUMDes yang sudah maju. Salah satu penyebab dari permasalahan ini adalah karena minimnya pendanaan yang diberikan kepada masyarakat. Masih banyak desa yang setengah hati mengalokasikan dana desa untuk BUMDes. ${ }^{14}$ Beliau menambahkan, pengalokasian dana yang diberikan hanya sekitar Rp 5-12 juta atau hanya sekitar 1-2 persen dari dana desa yang hampir mencapai Rp 800 juta. Hal tersebut sejalan dengan ungkapan yang didapat dari ketua Komite I Dewan Perwakilan Daerah Republik Indonesia (DPD RI), Akhmad Muqowam pada tahun 2017, bahwa Pemerintah dinilai kurang bijak dalam pelaksanaan Undang Undang Desa. Padahal apabila diamati secara lebih serius, pembinaan terhadap alokasi dana desa sangat penting terhadap program-program peningkatan pendapatan asli desa salah satunya melalui BUMDes.

\section{c) Solusi yang Ditawarkan}

Dalam hal ini, solusi yang ditawarkan dalam mengatasi masalah permodalan bagi Petani miskin adalah dengan optimalisasi penggunaan dana wakaf tunai, yang mana dana wakaf tunai ini sangat potensial karena banyaknya jumlah penduduk Muslim yang ada di Indonesia. Potensi wakaf tunai menurut data dari Badan Wakaf Indonesia (BWI) tahun 2018 mencapai sebesar Rp 180 triliun. Selain itu, konsep penyaluran dan pemberdayaan dana wakaf lebih luas dan tidak terbatas, bertolak belakang dengan dana zakat yang hanya diperuntukkan bagi 8 asnaf. Adapun teknis pengelolaan dana wakaf tersebut melalui pengembangan aplikasi Tanimu.com yang kedepannya akan di integrasikan dengan lembaga Badan Wakaf 2019. 
Muhammadiyah yang ada di Indonesia, yang kemudian dikerjasamakan dengan Badan Usaha Milik Desa (BUMDes) yang ada di Indonesia. Sehingga diharapkan masyarakat Petani dapat terbantu dalam meningkatkan hasil pertaniannya. Adapun contoh penyaluran dana wakaf tersebut dapat dilakukan melalui pembelian alat-alat pertanian yang berbentuk aset tetap dan akan dikelola oleh BUMDes, sehingga para Petani bisa berkolaborasi dengan BUMDes setempat dalam memanfaatkan wakaf tersebut, dengan begitu diharapkan seluruh Petani dapat merasakan manfaatnya dan dapat meningkatkan hasil pertaniannya.

\section{d) Skema Implementasi Gagasan}

Gagasan yang ditawarkan tentang penggunaan dana wakaf tunai untuk mengatasi masalah permodalan bagi petani menggunakan sebuah aplikasi bernama Tanimu.com yang berfungsi memberikan efisiensi dan kemudahan dalam implementasinya. Adapun skema implementasi gagasan tersebut terdapat pada gambar dibawan ini, yaitu tentang penghimpunan dan tata kelola wakaf tunai untuk pengembangan industri pertanian (Petani) di Indonesia dengan memanfaatkan peran BWM dan BUMDes pada aplikasi Tanimu.com dijelaskan sebagai berikut:

1. Penyerahan harta wakaf tunai oleh waqif, yang selanjutnya akan diserahkan kepada nazhir (BWM) secara online melalui peran aplikasi Tanimu.com dengan sistem crowdfunding. Tanimu.com merupakan aplikasi penggalangan dana wakaf tunai yang difokuskan untuk pembiayaan petani miskin di Indonesia.

2. Dana yang masuk di aplikasi Tanimu.com akan langsung dikelola oleh BWM, fungsi dari Tanimu.com hanya sebagai perantara sebelum dana waqif masuk ke rekening BWM dan diharapkan berguna untuk memudahkan masyarakat dalam berdonasi.

3. BWM akan bekerjasama dengan BUMDes dan membentuk tim khusus yang akan mengelola aplikasi Tanimu.com dan tim tersebut akan melakukan pendampingan kepada para Petani di setiap desa. 
4. Setelah melalui tahap pendampingan maka para Petani diwajibkan untuk melaporkan pengembangan usaha dan menyertakan laporan keuangannya ke pihak BUMDes yang kemudian akan di upload di aplikasi Tanimu.com setiap satu bulan sekali sebagai bukti transparansi kepada stakeholder.

Tanimu.com juga berfungsi sebagai media pemasaran hasil panen Petani. Sehingga Petani akan memiliki pangsa pasar yang semakin luas dan melakukan penjualan dengan cara yang efisien.

Gambar 1. Skema Penghimpunan dan Tata Kelola Dana Wakaf Tunai untuk Pengembangan Sektor Pertanian di Indonesia

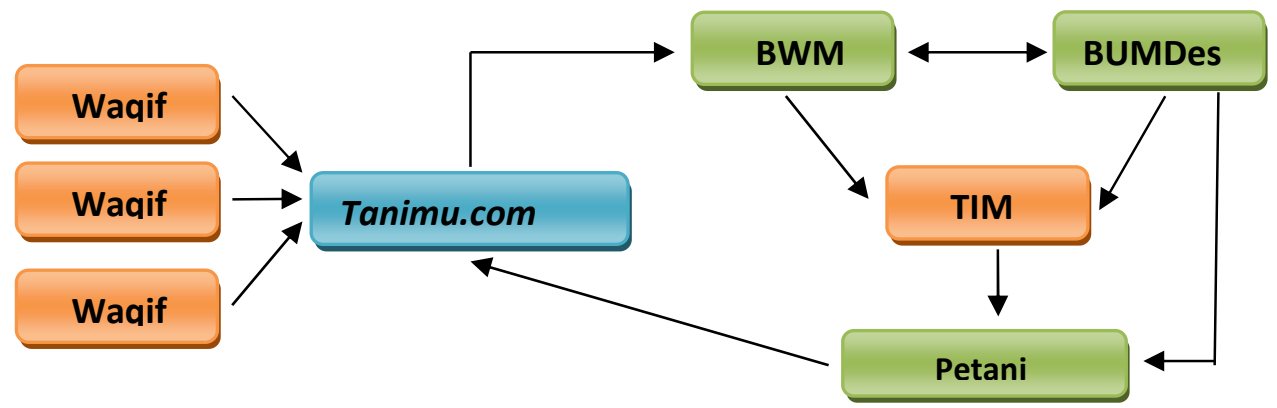

e) Bentuk Pemberdayaan Para Petani Menggunakan Konsep Sinergitas Para Stakeholder

Pengembangan sektor pertanian di Indonesia menggunakan dana wakaf tunai yang disalurkan ke BWM dan melalui aplikasi Tanimu.com masih membutuhkan kerjasama atau sinergi dengan para stakeholder untuk membantu dan mempercepat (akselerasi) secara signifikan. Gambar dibawah ini menggambarkan bentuk konsep sinergitas Tanimu.com dengan para stakeholdernya. Adapun peran dari masing-masing pihak dapat dijelaskan sebagai berikut:

1. Akademisi, Melalui pengalaman dan kapasitas keilmuan yang dimiliki, keduanya melakukan kolaborasi dalam menjalankan Research and Development dari sisi teknologi, inovasi produk serta sistem manajemen pengelolaan keuangan pada BWM. 
2. Pemerintah, meliputi pemerintah daerah dan kementerian terkait; a) Regulation Role, berupa kebijakan dalam penghimpunan dana Crowdfunding, b) Allocation Role, melalui BUMDes distribusikan berupa tenaga ahli, teknologi, dan infrasturuktur.

3. Komunitas, berperan sebagai katalisator melalui penyelenggaraan event atau sejenisnya guna mendukung promosi hasil panen Petani Indonesia.

4. Media, berfungsi sebagai pihak yang mengomunikasikan terhadap masyarakat luas tentang potensi dana wakaf tunai serta hasil panen Petani.

Gambar 2. Bentuk Pemberdayaan Menggunakan Sinergitas Para Stakeholder

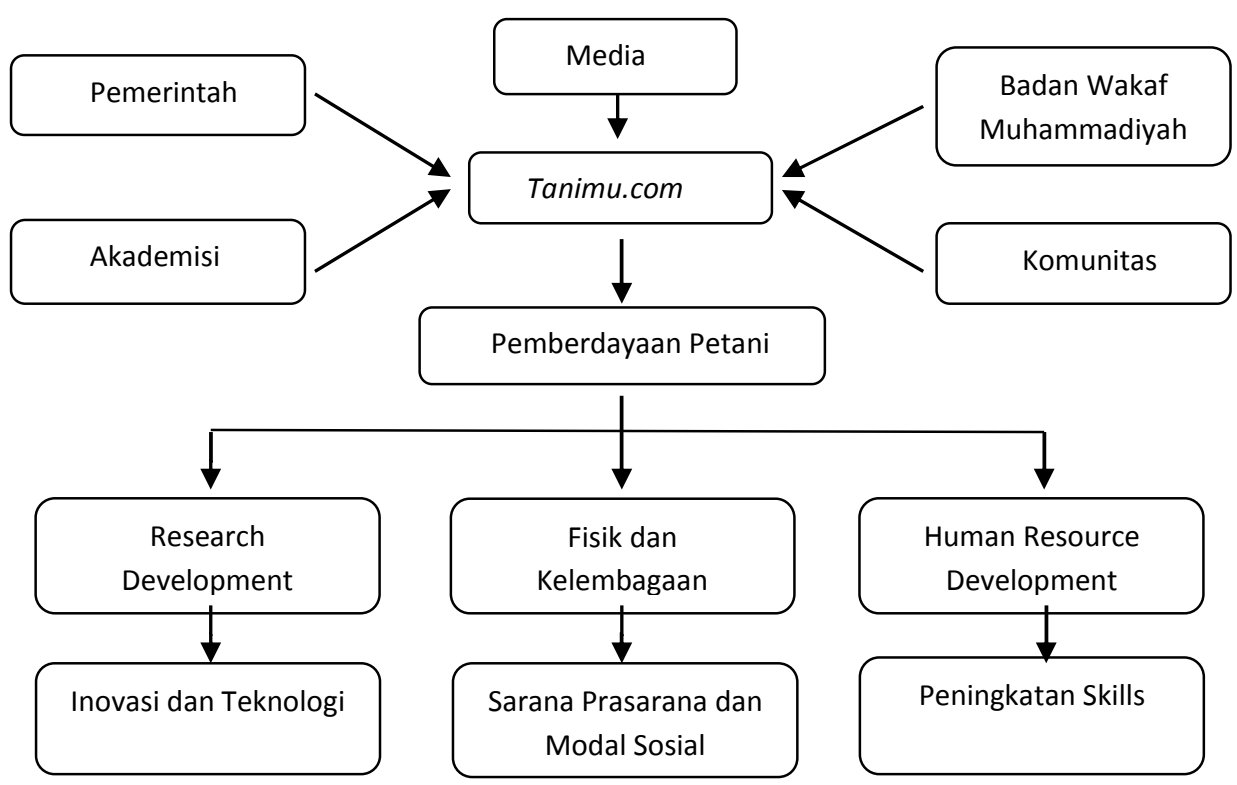




\section{f) Skema Alur Langkah-Langkah Strategis}

Langkah-langkah dalam pemberdayaan petani seperti dijelaskan dalam Gambar diatas adalah sebagai berikut:

1. Setiap Pedukuhan di desa melalui BUMDes diharuskan didaftarkan terlebih dahulu ke aplikasi Tanimu.com sebelum mendapatkan pendanaan dari BWI.

2. Setelah terdaftar, tim BWM akan melakukan pengecekan kelayakan Desa yang berhak mendapat pendanaan dari dana wakaf yang sudah terkumpul untuk pengadaan alat-alat bercocok tanam.

3. Setelah di sahkan oleh tim BWM dan terkumpulnya dana wakaf tersebut, BWM akan menugaskan BUMDes untuk melakukan pembelian alat-alat pertanian. Dalam hal ini wakaf tunai hanya dapat digunakan sebatas pembelian alat-alat dalam bidang pertanian, seperti traktor, alat mesin pemanen (rice combine harvester), alat penyemprot dan sebagainya; dan fasilitas pemasaran seperti laptop, printer, dan alat untuk mengemas produk. Alat-alat yang sudah dibeli akan disimpan dalam tempat khusus yang disebut lumbung alat. Sedangkan untuk keperluan bibit, pupuk, obat hama dan bahan habis pakai lainnya menggunakan dana desa yang dialokasikan ke BUMDes.

4. Sebagai bentuk transparansi, semua kebutuhan pertanian yang sudah dibeli akan di upload oleh BUMDes ke aplikasi Tanimu.com

5. Selanjutnya petani di setiap desa, akan mendapatkan pemberdayaan berupa pelatihan serta pendampingan oleh tim yang terdiri dari mahasiswa jurusan agroteknologi mengenai cara bercocok tanam yang baik dan modern. Kemudian petani membuat pembukuan mengenai perkembangan usaha pertaniannya dengan dipandu oleh tim yang terdiri dari mahasiswa jurusan akuntansi. Pembukuan ini juga akan dipantau oleh BWM.

6. Hasil panen petani selanjutnya dapat dijual di aplikasi Tanimu.com dengan panduan tim yang terdiri dari mahasiswa jurusan agribisnis, sehingga publik dapat melihat hasil perkembangan pertaniannya, dan hasil panen dapat dipasarkan sampai ke mancanegara. 
Gambar 3. Alur Kerja Aplikasi Tanimu.com Sebagai Sarana Pemberdayaan Petani Miskin Indonesia

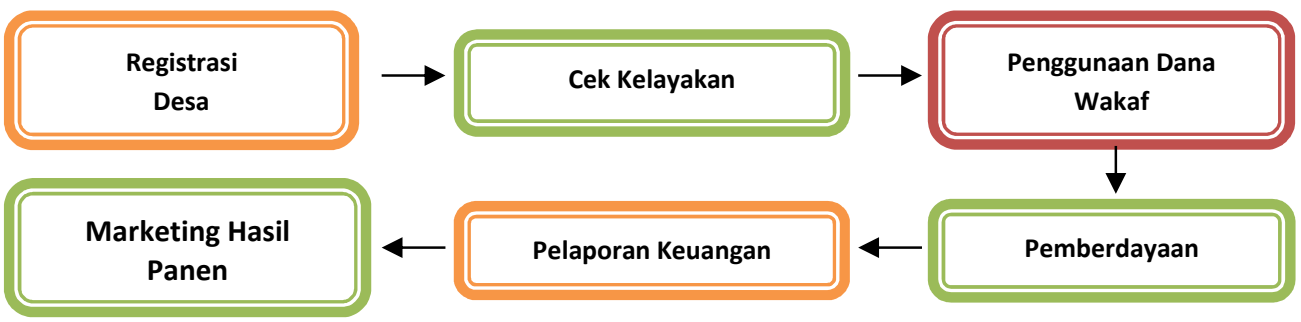

\section{Penutup}

Masalah sulitnya permodalan yang dialami oleh para petani Indonesia tidak bisa diabaikan begitu saja. Permasalahan ini haruslah mendapat perhatian penuh oleh pemerintah ataupun lembaga filantropi yang dapat memberikan solusi terhadap problematika tersebut. Hal tersebut dikarenakan sektor pertanian adalah salah satu sektor yang memiliki peran penting dalam pembangunan ekonomi bagi bangsa Indonesia. Kemiskinan dan kesejahteraan masyakat hampir 100\% dipengaruhi oleh sektor ini, karena sektor ini adalah penghasil bahan pangan utama bagi rakyat Indonesia. Tentunya suatu negara dengan kondisi pangan yang mencukupi tidak akan dilanda kemiskinan dan kondisi buruk lainnya.

Wakaf tunai merupakan sebuah alternatif yang sangat baik dalam memberikan solusi untuk melepas ketergantungan bangsa Indonesia dari lembaga-lembaga kreditor multilateral sekaligus menstimulasi pertumbuhan ekonomi Indonesia. Terlebih jika pengelolaan wakat tunai di sinergikan melalui system informasi digital akan memberikan maslahat yang sangat besar bagi masyarakat. Tanimu.com merupakan inovasi berbentuk aplikasi yang dibuat dengan tujuan membantu dan memudahkan para petani di Indonesia dalam memberikan solusi atas sulitnya permodalan yang didapatkan oleh para petani. Melalui aplikasi ini para petani akan didukung oleh BWM dengan menggunakan dana wakaf tunai yang akan dikerjasamakan dengan pihak BUMDes, sehingga para petani akan lebih mudah mendapatkan modal dalam bertani. Dalam hal ini para 
petani akan mendapatkan akses permodalan tanpa adanya timbal balik berupa bagi hasil atau bunga yang harus disediakan oleh petani, sehingga permodalan ini akan memberikan manfaat yang besar bagi petani dan tidak memberatkannya.

\section{Daftar Pustaka}

Departemen Agama RI. Al-Qur'an dan Terjemahan. Semarang: CV Toha Putra, 2010.

Abi Abdillah Muhammad bin Ismail al-Bukhari. Shahih Bukhari. Semarang: Toha Putera, 2009

Al-Minawi, Muhammad bin abdul Ra'uf. At-Taufiq ala Muhimat Ta'rif. Mesir: Alamul Qutub, 1990.

Al-Kabisi, Muhammad abid Abdullah. Anis Al-Fuqaha'. Jeddah: AlWafa' li An-Nashr wa Tauzi', 1987.

Al-Khattab, Abu Abdullah Muhammad bin Muhammad bin Abdurrahman al-Maghribi. Mawahibul Jalil ala Mukhtashar Khalil. Beirut: Dar al-Kutub Ilmiah, 1992.

An-Nawawi. Abu Zakaria Muhyiddin bin Syaraf, Tahrir Al-Fazh atTanbih. Damaskus: Darul Qolam, 1987.

Badan Pusat Statistik. Nilai Tukar Petani Nasional. Jakarta: Badan Pusat Statistik, 2019.

Badan Pusat Statistik. Presentase Penduduk Miskin dan Garis Kemiskinan. Jakarta: Badan Pusat Statistik, https://www.bps.go.id/pressrelease/2019/07/15/1629/persentasependuduk-miskin-maret-2019-sebesar-9-41-persen.html.

Diakses pada 17 Juli 2019

Badan Pusat Statistik. Persentasi Penduduk Miskin. Jakarta: Badan Pusat Statistik, 2018.

Charities Aid Foundation. World Giving Index. United Kingdom: Charities Aid Foundation 2017. 
Detiknews.com. Sekjen Kemendes: Alokasi Dana Desa untuk BUMDes Masih Minim., https://news.detik.com/berita-jawa-tengah/d3724861/sekjen-kemendes-alokasi-dana-desa-untuk-bumdesmasih-minim. Diakses 20 September 2019

Dewan Perwakilan Daerah Republik Indonesia (DPD RI) 2017. Komite I DPD RI: Dana Desa Belum Optimal, http://www.dpd.go.id/berita240-komite-i-dpd-ri-dana-desa-belum-optimal. Diakses $14 \mathrm{Mei}$ 2019

Hadad, Muliaman. “Stabilitas vs Pertumbuhan: Peranan Sektor Jasa Keuangan Dalam Perekonomian dan Tantangannya di Masa Depan 2018”. Orasi Ilmiah Guru Besar di Undip Semarang 2018.

Hardinawati L, Fauzy M. “Alasan Petani Muslim Menjual Hasil Panen Kepada Tengkulak di Desa Glagahagung, Kecamatan Purwoharjo, Kabupaten Banyuwangi". Proceeding 9 th ISDEV International Islamic Development Management Conference 2015.

Kominfo, Jumlah Pengguna Internet 2017 Meningkat, Kominfo akan Terus Lakukan Percepatan Pembangunan Broadband, https://kominfo.go.id/index.php/content/detail/12640/siaranpers-no-53hmkominfo022018-tentang-jumlah-penggunainternet-2017-meningkat-kominfo-terus-lakukan-percepatanpembangunan-broadband/0/siaran_pers. Diakses 25 Mei 2019

Syaifuddin. Kajian Sosial Ekonomi yang Mempengaruhi Kemiskinan Petani (Studi Kasus: Kecamatan Payung Kabupaten Karo). Agrica (Jurnal Agribisnis Sumatra Utara), vol. 4, no. 1, 2016. 